\title{
Established the Environmental Monitoring Program Indicators to Prevent Disease Infection and Promote Sustainable Development
}

\author{
Yi-Che Shih* \\ National Cheng Kung University, Central Police University, Taiwan \\ ${ }^{*}$ Corresponding author: Yi-Che Shih, Assistant Professor, National Cheng Kung University, Central Police University, Taiwan \\ Submission: 跙: October 03, 2018; Published: 畊 October 05, 2018
}

\section{Introduction}

Marine aquaculture may also cause environmental degradation from feces, uneaten feed and use of chemicals if the local carrying capacity is exceeded [1]. The most important benthic impact relates to the formation of anoxic sediments [2-4] which can be easily monitored. Both sediment condition and waste accumulation are good indicators for detecting the environmental condition at aquaculture sites. Beveridge [5] revealed that environmental deterioration because of high organic matter concentrations in the sediments may affect the health of farmed fish and hence profitability. Waste and waste-makes quality management for marine aquaculture in other countries has not only focused on the release limitations of organic matter, and nutrients [6-8] but also on chemicals [9] used on the farms regardless wherever into estuaries or nearshore coastal waters $[10,11]$. This investigation uses an environmental monitoring program to understand and assess the environmental impact of marine farming.

Environmental monitoring program ratings for the near-field effects from trace metals in sediments [12]. Waste management for marine aquaculture in other countries has focused on the release of organic matter, nutrients, and chemicals directly from the farms into estuaries and coastal waters. Finfish farms need more extensive programs for the management of waste than shellfish farms, because finfish provide exogenous food sources [10]. Redox potential is useful as an indicator of the degree of microbial activity in organically-enriched sediments $[13,14]$. Here we used an EMP to determine and assess the environmental impact of farming.

\section{Environmental monitoring program}

Currently there are very limited approaches for assessing the impacts of aquaculture on sediment with the exception of the environmental monitoring program (EMP), implemented by the Department of the Environment, New Brunswick, Canada. EMP is based on sediment redox potential, sulfide concentrations, and video transects data for monitoring environmental effects of salmon aquaculture operations [15]. The impacts are considered unacceptable when sediments become anoxic. There is a need for the development of more sensitive tools and methods for detecting environmental effects of aquaculture and for determining what constitutes acceptable and unacceptable impacts. Other sediment chemistry indicators of environmental effects would assist in assessing the sustainability of aquaculture operations. The environmental monitoring program (EMP) approach was adopted to evaluate the marine environmental impact of cobia marine aquaculture environmental management $[16,17]$. The EMP ratings were assessed by the diver on site following the guidelines defined by the Department of Environment and Local Government of New Brunswick, Canada [15]. Redox potential in core samples was measured with a Fisher Scientific Co., USA. AP-63 (PH/MV/Temp/ Ion), using methods described by Wildish et al. [18] The sulfide probes were calibrated just before use on each sampling day by checking against freshly prepared $\mathrm{Na} 2 \mathrm{~S}$ ? $9 \mathrm{H}_{2} \mathrm{O}$ solutions at three concentrations $(10 \mu \mathrm{M}, 100 \mu \mathrm{M}$ and $1000 \mu \mathrm{M})$. Sediment samples were mixed immediately after collection with sulfide antioxidant buffer (SOAB from Fisher Science Co.) (1:1v/v). Sulfide levels were recorded in millivolts $(\mathrm{mV})$ when the reading stabilized. These methods were confirmed experimentally [16-18].

The study shows that assessment of the marine environment at aquaculture sites requires a tool beyond the environmental monitoring program (EMP) rating. The sediment chemistry response to changes in environmental conditions at the aquaculture sites clearly result in differences from natural background sediment levels. Those changes make the modeling approach feasible in this study and useful for interpreting the impact of the aquaculture activities to the environment. This approach provides an effective means for assessing the environmental conditions based on sediment chemistry, and consequently in establishing regulatory guidelines to establish baseline information, such as marine environmental quality, sediment remediation or degradation in relation to the aquaculture conditions.. 


\section{References}

1. Wildish DJ, Keizer PD, Wilson AJ, Martin JL (1993) Seasonal changes of dissolved oxygen and plant nutrients in seawater near net pens in the macrotidal Bay of Fandy. Canadian J Aquat Sci 50(2): 303-311.

2. Blackburn TH, Lund BA, Krom MD (1988) C- and N-mineralisation in the sediments of earthen marine fishponds. Mar Ecol Prog Ser 44(3): 221 227.

3. Hargrave BT, Duplisea DE, Pfiffer E, Wildish DJ (1993) Seasonal changes in benthic fluxes of dissolves oxygen and ammonium associated with marine cultured Atlantic salmon. Mar Ecol Prog Ser 96: 249-257.

4. Wu RSS, Lam KS, Mackay DW, Lau TC, Yam V (1994) Impact of marine fish farming on water quality and bottom sediment: a case study in the sub-tropical environment. Mar Environ Res 38(2): 115-145.

5. Beveridge MCM (1996) Cage Aquaculture, Ed.2, Fishing News Books, Oxford, UK, pp. 346.

6. Chao-Kai Yang, Wen-Yan Chiau, Yi-Che Shih (2016) Sediment characteristics under and around cobia cage farms at Penghu, Taiwan, as visualized by Redox potential and sulfide content profiles using GIS as documentation tool. Journal of Aquaculture \& Marine Biology 4(6): 00101.

7. Read PA, Fernandes TF, Miller KL (2001) The derivation of scientific guidelines for best environmental practice for the monitoring and regulation of marine aquaculture in Europe. J Appl Ichthyol 17(4): 146-152.

8. Rosenthal H (1994) Fish farm effluents and their control in EC countries: summary of a workshop. J Appl Ichthyol 10(4): 215-224.

9. Sano T (1998) Control of fish disease, and the use of drugs and vaccines in Japan. J Appl Ichthyol 14(3-4): 131-137.

10. Crawford CM (2003) Environmental management of marine aquaculture in Tasmania, Australia. Aquaculture 226(1-4): 129 -138.
11. Henderson A, Gamito S, Karakassis J, Pederson P, Small A (2001) Use of hydrodynamic and benthic models for managing environmental impacts of marine aquaculture. J Appl Ichthyol 17(4): 163-172.

12. Chou CL, Haya K, Pao LA, Moffatt JD (2002) Aquaculture-related trace metals in sediments and lobsters and relevance to environmental monitoring program ratings for near-field effects. Mar Poll Bull 44(11): 12591268.

13. Midlen A, Redding TA (1998) Environmental management for aquaculture. Chapman \& Hall, New York, USA

14. Yi-Che Shih, Chiu CL, Wen-Yan Chiau (2009) Geographic information system applied to measuring benthic environmental impact with chemical measures on mariculture at Penghu Islet in Taiwan. Science of the Total Environment 407(6): 1824-1833.

15. DELG (2000) Environmental management guidelines for the Atlantic salmon marine cage aquaculture industry in New Brunswick Final Draft, (EMG) Version 1.00 Section 3 of 4. Environmental Quality Objectives and Monitoring Programs, 22 August.

16. Chou CL, Haya K, Paon LA, Moffatt JD (2004) A regression model using sediment chemistry for the evaluation of marine environmental impacts associated with salmon aquaculture cage wastes. Mar Pollute Bull 49(56): 465-472

17. Yi-Che Shih (2018) Marine environmental management and development strategy for marine aquaculture in Taiwan: Cobia Case Study. Advances in Oceanography \& Marine Biology 1(1): 2018.

18. Wildish DJ, Akagi HM, Hamilton N, Hargrave BTA (1999) Recommended method for monitoring sediments to detect organic enrichment from maricultural in the Bay of Fundy. Canadian Technical Report of Fisheries and Aquatic Sciences 2286: 1-31.

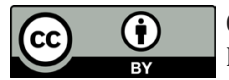

Creative Commons Attribution 4.0 International License

For possible submissions Click Here

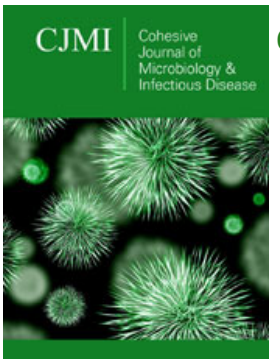

Cohesive Journal of Microbiology \& Infectious Disease

\section{Benefits of Publishing with us}

- High-level peer review and editorial services

- Freely accessible online immediately upon publication

- Authors retain the copyright to their work

- Licensing it under a Creative Commons license

- Visibility through different online platforms 